Acta Theriologica 43 (1): 77-94, 1998.

PL ISSN 0001-7051

\title{
Seasonal composition and quality of red deer Cervus elaphus diets in northeastern China
}

\author{
Huapeng CHEN, Jianzhang MA, Feng LI, Zhongwu SUN, Huai WANG, \\ Liyang LUO and Fei LI
}

Chen H., Ma J., Li F., Sun Z., Wang H., Luo L. and Li F. 1998. Seasonal composition and quality of red deer Cervus elaphus diets in northeastern China. Acta Theriologica 43: 77-94.

Seasonal composition and quality of diets of red deer Cervus elaphus Linnaeus, 1758 were investigated, basing on microhistological analysis of composite fecal samples in the Less Xingan Mountains, northeastern China. Red deer consumed more graminoids $(46 \%)$ in spring, shifted to forbs $(45 \%)$ in summer, and returned to graminoids $(35 \%)$ in autumn. Availability and high quality [high level of crude protein $(\mathrm{CP})$, and low level of neutral detergent fiber (NDF) and acid detergent fiber (ADF) in forbs in summer] appeared to be two key factors causing these changes in diets. Winter diets were dominated by browses (74\%) and the horsetails Equisetum hiemale (21\%). Three forbs (Oxalix corniculata, Caltha palustris, Agrimonia pilosa) were prevalent in diets during snow-free seasons, and aspen (Populus spp.) was an important browse species in all seasons, especially in winter $(32 \%)$. Forage and diet quality changed seasonally. Dietary CP and in vitro dry matter digestibility (IVDMD) declined significantly from spring to winter (from 19.6 to $6.4 \%$ and from 61.1 to $32.9 \%$, respectively). In contrast, dietary NDF and ADF increased from 55.6 to $69.9 \%$ and from 27.9 to $54.3 \%$, respectively. Red deer diets showed different patterns of seasonal variation in mineral contents. In most cases, dietary $\mathrm{Ca}, \mathrm{P}$ and $\mathrm{K}$ were adequate, but $\mathrm{Na}$ appeared deficient all the year round. It is concluded that red deer in this region are typical mixed feeders and their diet shows seasonal changes in quality, similar to those of North American wapiti. Although red deer may have enough protein in most seasons, energy might be a key limiting factor in severe winters.

College of Wildlife Resources, Northeast Forestry University, Harbin 150040, P. R. China; e-mail: hp@public.hr.hl.cn

Key words: Cervus elaphus, diet composition, forage quality, diet quality

\section{Introduction}

Intermediate forms between European red deer and North American wapiti occur across Asia (Clutton-Brock et al. 1982). Cervus elaphus Linnaeus, 1758 is widely distributed from central to northern China and eight subspecies are identified in the whole country (Sheng and Ohtaishi 1993). The subspecies C. e. xanthopygus (Mine-Edwards, 1867) from northeastern China is extremely close to the larger phenotype, North American wapiti C.e. canadensis in morphology and behaviour (Geist 1987, Ohtaishi and Gao 1990). Although the populations of Cervus 
elaphus was estimated at 100000 to 200000 throughout the country (Sheng and Ohtaishi 1993), it was listed as a second ranked protected species (Ohtaishi and Gao 1990, Sheng 1992) since its populations have been declining as a result of illegal hunting and losses of suitable habitats caused by human activities.

Body size, rumino-reticular volume, mouth size, and incisor breadth impose important constraints on diet selection in wild ruminants (Hanely 1982, Demment and Van Soest 1985, Baker and Hobbs 1987, Hofmann 1989, Illius and Gordon $1987,1990)$. Because the ratio of nutrient requirements to gut capacity scales with a negative allometric exponent, it has been argued that large-sized ruminants have relatively low mass-specific energy requirements and thus are adapted to feed on less energy-dense and low quality food items (Bell 1970, 1971, Jarman 1974, Gordon and Illius 1996). Red deer has been classified as an intermediate or mixed feeder (Hofmann and Stewart 1972, Hofmann 1989) and was thought to be an opportunistic feeder that is highly variable and flexible in seasonal diet selection (Hofmann 1989). Results from the extensive studies on composition and quality of diets in European red deer (Gębczyńska 1980, Jamrozy 1980, Clutton-Brock and Albon 1989, Matrai and Kabai 1989) and North American wapiti (Hobbs et al. 1981, Baker and Hobbs 1982, Nelson and Leege 1982, Rowland et al. 1983, Leslie et al. 1984, Morgantini and Hudson 1989, Jenkins and Starkey 1993, Merrill 1994, Gogan and Barrett 1995, Merrill et al. 1995) tend to support this. More recently, Merrill (1994) emphasized that seasonal change in availability of forbs may be crucial to changes of food items in wapiti diets. Although a few studies have been reported on food habits of red deer in China (Chen and Xiao 1989, Li and Yan 1989, Li et al. 1992, Chen et al. 1993), much remains unknown on seasonal composition and quality of diets. Despite wide regional variation that exists in diet composition, it is still expected that red deer in our study area may have similar pattern of diet selection predicted by Hofmanns theory and diet quality similar to that of European red deer and North American wapiti. The purpose of present study was to evaluate these two predictions.

\section{Study area}

The study was conducted at Tonghe Hunting Farm, which is situated on the southern slope of the Less Xingan Mountains ( $45^{\circ} 43^{\prime} \mathrm{N}, 128^{\circ} 40^{\prime} \mathrm{E}$ ), northeastern China and occupies 30000 ha. Tonghe is a low mountain area with an average elevation of $600 \mathrm{~m}$. The weather is continental and characterized by long, cold winters, and short, hot summers. The annual average temperature is $2.4^{\circ} \mathrm{C}$, and extreme temperatures range from about $-40.4^{\circ} \mathrm{C}$ to $36.7^{\circ} \mathrm{C}$. The accumulated temperature above $10^{\circ} \mathrm{C}$ is $2200-2500^{\circ} \mathrm{C}$. The average annual precipitation is about $560-700 \mathrm{~mm}$. The frost-free period is 100-105 days, from late April to late September. Snow accumulates in late November, and persists until end of April, and the average snow depth is $43 \mathrm{~cm}$.

Typical vegetation is coniferous-deciduous and deciduous forest. The investigation conducted in winter of 1991, using the point-quarter sampling method (Goldsmith and Harrison 1976), showed that major trees were Fraxinus mandshurica (17.3\% of relative density), Pinus koraiensis (15.1\%), Tilia anmurensis (15.1\%), Phellodendron amurense (8.5\%), Ulmus spp. (5.9\%), and Acer mono (3.7\%) 
(H. Chen et al., unpubl.). Understorey shrubs mainly include Corylus mandshurica, Deutzia spp., Lonicera spp., Syringa amurensis, and Acanthopanas senticosus. Common herbaceous layer plants in forests are Carex spp., Urtica spp. and Aegopodium alpestre.

\section{Material and methods}

\section{Diet composition}

Diet composition was determined by identification of plant cuticular fragments in composite fecal samples. In mid-May 1991, a total of 14 permanent sampling strips $(500 \times 4 \mathrm{~m})$ oriented east-west were established across 5 feeding sites for collecting fresh pellet groups during snow-free seasons. In October 1991 additional 10 strips were set up. Parallel strips were distributed at least $500 \mathrm{~m}$ from one another. Examination of each strip was completed by 2 persons each month and feces were collected until October 1992. In winter, pellet groups were collected following fresh tracks. Pellet groups collected each month from June 1991 to October 1992 were pooled in 4 composite seasonal samples (one pellet from each pellet group), namely spring (45 pellet groups, May), summer (91 pellet groups, June-August), autumn (152 pellet groups, September-October) and winter (570 pellet groups, November-April). Composites were demonstrated to be representative of individual samples in the study of deer nutritional ecology and save much in time and costs despite loss of sample variability (Jenks et al. 1989). About 125 plant species were collected from feeding habitats and 2 sets of reference slides were prepared according to Storr (1961) and using the same procedure as fecal slides, respectively.

Fecal samples were oven-dried at $70^{\circ} \mathrm{C}$ for $24 \mathrm{hr}$ and thoroughly ground. Ground materials were screened through a $0.15 \mathrm{~mm}$ sieve to eliminate tiny fragments that were usually unidentifiable. Samples from spring, summer and autumn, and winter were treated by mixed solution of $10 \%$ chromic acid and $10 \%$ nitric acid (1:1), and concentrated nitric acid, respectively, according to the procedure described by Anthony and Smith (1974), Chen and Xiao (1989), and Gao et al. (1991). Thirty slides were prepared from each composite sample and 20 fields of each slide were examined at 100 following Sparks and Malechek (1968). Results were expressed by the relative density of fragments of each food item in each microscopic field, converted from frequency of each food item (Fracker and Brischle 1944).

\section{Forage and diet quality}

Forages (food samples) were collected in July, September, November, January, March, and May from 1991 to 1992, at the same 5 feeding sites as those for diet composition. Sedges, forbs, and ferns were collected by simulating the foraging manner of red deer, from at least 10 different plants at each site. Current annual growth of 14 browse species was collected from at least 20 plants at 5 sites. Samples were oven-dried at $70^{\circ} \mathrm{C}$ for $48 \mathrm{hr}$ and ground through a $0.5-\mathrm{mm}$ mesh in a plant mill. Five composite samples (one sample for each of 5 sites) of sedges, forbs, and ferns for each sampling period were made, respectively, by combining equal amount of ground plant materials of each species. For sedges, forbs and ferns, 4, 8 and 4 species were included, respectively, which were Carex callitirchos, C. campylorhina, C. lanceolata, and C. siderosticta (sedges), Oxalix corniculata, Caltha palustris, Agrimonia pilosa, Anemon raddeana, Veronica sibirica, Vicia cracca, Cacalia hastata, and Maianthemum bifolium (forbs), Pteridium aquilinum, Adiantum pedatum, Athyrium acrostichoides, and Dryopteris crassirhizoma (ferns). Duplicate subsamples were analyzed for crude protein (CP) by the macro-Kjeldahl technique (Cullison 1982); neutral detergent fiber (NDF) and acid detergent fiber (ADF) according to Goering and Van Soest (1970); calcium (Ca), sodium (Na) and potassium (K) by atomic absorption spectrophotometry; and phosphorus (P) by spectrophotometry.

In vitro dry matter digestibility (IVDMD) was determined by 2 -stage technique of in vitro trial following Pearson (1970), but it was modified by using $50 \mathrm{ml}$ centrifuge tubes, each containing a $0.3 \mathrm{~g}$ 
subsamples and a $30 \mathrm{ml}$ mixture of buffer solution and rumen liquid (4:1). Rumen inoculum was obtained from one red deer captured from its natural habitat in November 1993. The interval from killing the animal to conducting the digestion trial was $<30$ minutes. Forages were measured in duplicate and 5 blanks were used in the trial.

We estimated diet quality following Urness et al. (1975). For each nutrient, the percent a plant species contributed to the seasonal diets was multiplied by its chemical concentration to yield a weighted nutritional value, and then the nutrient content of seasonal diets was estimated by dividing the summed weighted nutritional values across species by the percent of the total diet accounted for the species analyzed that season. For winter diets, average nutrient values from three sampling periods (November, January and March) were used in the calculation of diet quality.

The other method to estimate diet quality was to include all forage items occurring in the feces in the calculation and the value of the specific nutrient was obtained by summing up the nutrient content of each forage weighted by its proportion in the feces. This method was used by Leslie et al. (1984), Jenkins and Starkey (1993), and Merrill et al. (1995) in the comparative analysis for the diet quality. Based on the simulated samples produced from the data of diet composition and nutrient contents of forages in this study and Leslie et al. (1984), we compared the estimates of the diet nutritional quality using above two methods, and found that results from two methods were very close and no significant difference existed between two methods when the percent of total diet accounted for the forages analyzed was over $60 \%$ like this study $(67-81 \%)$. Thus, we believed that the errors from the different manner of calculating diet quality could be ignored in the comparative analysis.

\section{Statistical analysis}

Differences among seasonal diet composition were tested using $\chi^{2}$-test. When the null hypothesis was rejected, Bonferroni simultaneous confidence intervals were further established to indicate differences among forage classes (Byers et al. 1984). A Spearman rank correlation coefficient $\left(r_{\mathrm{S}}\right)$ (Steel and Torrie 1980) was used to examine seasonal trends in diet quality. We compared diet composition and quality of red deer in our region with those of North American wapiti because we required that diet composition data come only from the fecal analysis in all comparable studies and no such data were available from European red deer, using a principal component analysis (SAS 6.0 1989). In the comparison, forages were divided into graminoids (grasses and sedges), forbs, and browses, and seasons were delineated as follows: May as spring, June-August as summer, September-October as autumn, and November-April as winter if seasons were not clearly indicated and sampling periods were given by months in the comparable studies. Average values across months or years were used in the comparative analysis when diet composition and quality data were given by months and years in some studies. For the comparison of diet quality, a scatter plot showing cluster membership at selected levels of 4 instead of the tree diagram was produced by the SAS ANALYZE macro procedure (SAS 6.0 1989). One-sample $T$-test (Steel and Torrie 1980) was used to determine difference in red deer diet quality between our study area and North American.

\section{Results}

\section{Diet composition}

Red deer showed significant variation in diet composition among seasons $\left(\chi^{2}\right.$-test: $\chi^{2}=35.9$ for spring-summer, $\chi^{2}=8.2$ for spring-autumn, $\chi^{2}=9.0$ for spring-winter, $\chi^{2}=22.7$ for summer-autumn, $\chi^{2}=22.4$ for summer-winter, $\chi^{2}=10.8$ for autumn-winter; $p<0.05$ for all comparisons) (Table 1 ). The diet was dominated by graminoids $(46 \%)$ in spring, shifted to forbs $(45 \%)$ in summer, and returned to graminoids $(35 \%)$ in autumn. Twigs of browses were dominant in the 
Table 1. Seasonal composition $(\%)$ of red deer diets in the Less Xingan Mountains, northeastern China (1991-1992). Different letters in the same row indicate a significant difference at $p<0.05$.

\begin{tabular}{|c|c|c|c|c|}
\hline Taxa & Spring & Summer & Autumn & Winter \\
\hline \multicolumn{5}{|l|}{ Graminoids } \\
\hline Carex spp. & 36.0 & 18.1 & 26.4 & $<1.0$ \\
\hline Gramineae & 10.4 & 7.0 & 8.3 & $<1.0$ \\
\hline Subtotal & $46.4^{\mathrm{a}}$ & $25.1^{\mathrm{b}}$ & $34.7^{\mathrm{b}}$ & $1.3^{\mathrm{c}}$ \\
\hline \multicolumn{5}{|l|}{ Forbs } \\
\hline Oxalix corniculata & 6.4 & 5.5 & 2.4 & - \\
\hline Caltha palustris & 6.4 & 12.1 & 4.3 & - \\
\hline Agrimonia pilosa & 1.6 & 21.6 & 6.7 & - \\
\hline Other & 4.4 & 6.0 & 12.6 & $<1.0$ \\
\hline Subtotal & $18.8^{\mathrm{a}}$ & $45.2^{\mathrm{b}}$ & $26.0^{\mathrm{a}}$ & $<1.0^{\mathrm{c}}$ \\
\hline \multicolumn{5}{|l|}{ Browses } \\
\hline Populus spp. & 7.6 & 12.1 & 7.7 & 31.6 \\
\hline Salix spp. & $<1.0$ & 1.5 & 2.4 & 9.9 \\
\hline Betula spp. & 1.2 & 2.0 & 4.3 & 6.9 \\
\hline Pinus koraiensis & $<1.0$ & 1.5 & 1.2 & 13.8 \\
\hline Other & 9.2 & 6.0 & 11.3 & 12.1 \\
\hline Subtotal & $19.6^{\mathrm{a}}$ & $23.1^{\mathrm{a}}$ & $26.9^{\mathrm{a}}$ & $74.3^{b}$ \\
\hline Unknown forbs and browses & 4.8 & 4.0 & 4.0 & 1.7 \\
\hline \multicolumn{5}{|l|}{ Ferns } \\
\hline Equisetum hiemale & $<1.0$ & 2.0 & 20.9 & - \\
\hline Other & 6.4 & 2.0 & 4.7 & 1.5 \\
\hline Subtotal & $6.8^{\mathrm{a}}$ & $2.0^{\mathrm{a}}$ & $6.7^{\mathrm{a}}$ & $22.4^{\mathrm{b}}$ \\
\hline Mosses & $1.2^{\mathrm{a}}$ & $<1.0^{\mathrm{a}}$ & $2.0^{\mathrm{a}}$ & - \\
\hline
\end{tabular}

winter diet (74\%). Red deer consumed more graminoids in spring than in other seasons $(p<0.05)$, and more forbs in summer than in spring and autumn $(p<0.05)$. They maintained a relatively constant level of browses in diets during snow-free seasons $(p>0.05)$. Although ferns were often eaten in small amounts during snow-free seasons, they increased in winter $(22 \%)$ due to the dramatic increase of horsetail Equisetum hiemale in diets $(p<0.05)$. Red deer rarely ate mosses in all seasons.

The majority of forbs eaten during snow-free seasons was Oxalis coriculate, Caltha palustris and Agrimonia pilosa, which comprised $52-87 \%$ of the forb component of the diets. Populus spp. was an important browse species in all seasons, especially winter. Other principal items in winter diets included Equisetum hiemale, Pinus koraiensis, Salix spp. and Betula spp.. Consumption of Pinus koraiensis peaked in winter (Table 1). 


\section{Forage and diet quality}

Concentrations of CP and IVDMD in all types of forages were generally highest in spring, decreased through summer and autumn, and reached their lowest point in winter, whereas contents of fiber components (NDF and ADF) were lowest in spring and increased as plant tissue matured (Table 2). Similarly, from spring through winter dietary CP and IVDMD declined significantly $\left(r_{\mathrm{S}}=1, p<0.05\right)$. CP decreased about three-fold from 19.6 to $6.4 \%$, and IVDMD about two times from 61.1 to $32.9 \%$ (Table 3). In contrast, dietary NDF and ADF increased consistently through winter. Although a significant seasonal trend existed in dietary $\operatorname{NDF}\left(r_{\mathrm{S}}=-1, p<0.05\right)$ rather than in $\operatorname{ADF}\left(r_{\mathrm{S}}=-0.4, p>0.05\right)$, the magnitude of change in dietary NDF was smaller than $\mathrm{ADF}$.

Dietary $\mathrm{Ca}$ and $\mathrm{Na}$ increased continually from spring to autumn and then dropped in winter, but dietary $\mathrm{P}$ and $\mathrm{K}$ showed different patterns and increased from spring to summer, reaching the highest level, and then decreased continually from summer to winter (Table 3). However, no consistent seasonal trends were found in dietary minerals $\left(r_{\mathrm{S}}\right.$ were -0.4 for $\mathrm{Ca},-0.2$ for $\mathrm{P}, 0.2$ for $\mathrm{Na}$, and 0.8 for $\mathrm{K}, p>0.05$ ).

\section{Comparisons of red deer diet composition and quality}

Comparisons of red deer diet composition and quality between our region and North America were summarized in Figs 1 and 2. In Fig. 1, 15 studies including. this study were plotted together based on the principal component analysis of seasonal diet composition, with the first principal component as $\mathrm{X}$ axis and the second principal component as $\mathrm{Y}$ axis. The first 2 principal components account for $97 \%$ of the variance. The first principal component represents changes in the proportions of graminoids in the diets, decreasing from the left to the right of $\mathrm{X}$ axis and the second principal component reflects changes in the proportions of forbs in the diets, rising as values of $\mathrm{Y}$ axis increase. Seasonal variation in diet composition was evident from Fig. 1 and a certain similarity existed between our results and those from North America wapiti. A wider variation in diet composition was found in spring than other seasons, whereas a larger similarity existed in summer and autumn diet composition between our study area and North America. Two groups could be identified in the winter diet composition, one located on the low left corner indicating that graminoids were dominant in the diets, the other on the low right corner indicating that browses were staple components in the diets. This study fell in the later and was farthest on the left with over $70 \%$ of the diets being browse twigs.

In contrast with wide regional variation in diet composition, red deer in our study area had similar seasonal nutritional quality of diets both in CP contents and IVDMD to those of North American wapiti $(p>0.05)$. The same seasonal changes in red deer diet quality existed between our region and North America (Fig. 2). Exceptionally high and low dietary IVDMD values were reported by 
Table 2. Chemical composition of principal forages consumed by red deer in the Less Xingan Mountains, northeastern China (1991-1992). CP - crude protein $(\%), \mathrm{NDF}$ - neutral detergent fiber $(\%), \mathrm{ADF}$ - acid detergent fiber $(\%)$, IVDMD - in vitro dry matter digestibility $(\%), \mathrm{Ca}$ - calcium $(\%)$, $\mathrm{P}$ - phosphorus $(\%), \mathrm{Na}$ - sodium ( $\mu \mathrm{g} / \mathrm{g}), \mathrm{K}$ - potassium $(\%),{ }^{a}$ twigs with leaves in spring, summer, and autumn, and only twigs in winter.

\begin{tabular}{|c|c|c|c|c|c|c|c|c|}
\hline \multirow{2}{*}{ Taxa } & \multicolumn{8}{|c|}{ Components } \\
\hline & $\mathrm{CP}$ & $\mathrm{NDF}$ & $\mathrm{ADF}$ & IVDMD & $\mathrm{Ca}$ & $\mathrm{P}$ & $\mathrm{Na}$ & $\mathrm{K}$ \\
\hline \multicolumn{9}{|l|}{ Carex spp. } \\
\hline Spring & 15.30 & 65.80 & 29.04 & 62.50 & 0.26 & 0.16 & 187.66 & 2.23 \\
\hline Summer & 10.12 & 76.75 & 44.46 & 59.96 & 0.22 & 0.41 & 144.85 & 2.11 \\
\hline Autumn & 11.56 & 77.38 & 47.56 & 48.72 & 0.37 & 0.29 & 126.59 & 1.60 \\
\hline \multicolumn{9}{|l|}{ Forbs } \\
\hline Spring & 22.18 & 40.24 & 20.55 & 64.30 & 0.77 & 0.36 & 93.66 & 3.72 \\
\hline Summer & 15.04 & 57.19 & 42.02 & 56.59 & 1.41 & 0.39 & 177.32 & 3.91 \\
\hline Autumn & 12.32 & 56.65 & 37.76 & 51.07 & 2.84 & 0.42 & 304.40 & 2.82 \\
\hline \multicolumn{9}{|l|}{ Ferns } \\
\hline Spring & 28.80 & 64.38 & 44.99 & 52.49 & 0.25 & 0.40 & 200.99 & 3.39 \\
\hline Summer & 14.98 & 71.32 & 53.50 & 48.76 & 0.68 & 0.28 & 172.17 & 2.86 \\
\hline Autumn & 9.16 & 70.08 & 67.46 & 39.53 & 0.87 & 0.29 & 121.37 & 2.71 \\
\hline \multicolumn{9}{|c|}{$\begin{array}{l}\text { Browses }^{\mathrm{a}} \\
\text { Populus spp. }\end{array}$} \\
\hline Spring & 17.87 & 48.79 & 33.69 & 51.84 & 0.55 & 0.27 & 92.84 & 1.21 \\
\hline Summer & 10.20 & 72.53 & 61.01 & 50.17 & 1.05 & 0.35 & 136.24 & 1.26 \\
\hline Autumn & 8.44 & 78.65 & 64.27 & 45.64 & 1.44 & 0.43 & 192.33 & 1.04 \\
\hline Winter & 6.60 & 72.03 & 53.67 & 33.20 & 0.79 & 0.32 & 97.82 & 1.61 \\
\hline \multicolumn{9}{|l|}{ Betula spp. } \\
\hline Spring & 27.90 & 57.61 & 39.84 & 44.06 & 0.31 & 0.19 & 126.06 & 0.74 \\
\hline Summer & 11.19 & 72.02 & 49.98 & 42.15 & 0.56 & 0.41 & 146.85 & 1.25 \\
\hline Autumn & 9.31 & 60.58 & 46.93 & 37.89 & 0.50 & 0.23 & 77.56 & 0.68 \\
\hline Winter & 7.98 & 66.16 & 53.62 & 28.62 & 0.30 & 0.37 & 143.39 & 0.28 \\
\hline \multicolumn{9}{|l|}{ Salix spp. } \\
\hline Spring & 22.69 & 58.85 & 44.78 & 57.63 & 0.68 & 0.37 & 158.90 & 1.07 \\
\hline Summer & 14.65 & 66.94 & 53.56 & 48.32 & 0.98 & 0.33 & 132.61 & 1.50 \\
\hline Autumn & 8.37 & 65.21 & 49.69 & 43.81 & 1.81 & 0.17 & 114.63 & 1.01 \\
\hline Winter & 5.81 & 72.03 & 61.46 & 31.86 & 0.43 & 0.37 & 137.44 & 0.38 \\
\hline \multicolumn{9}{|c|}{ Aralia mandshurica } \\
\hline Spring & 29.79 & 55.09 & 20.84 & 58.83 & - & - & - & - \\
\hline Autumn & 5.71 & 68.41 & 49.74 & 39.76 & - & - & - & - \\
\hline Winter & 11.48 & 58.94 & 46.47 & 42.29 & 0.84 & 0.22 & 131.44 & 0.95 \\
\hline \multicolumn{9}{|c|}{ Acanthopanax senticosus } \\
\hline Autumn & 6.89 & 74.37 & 50.72 & 42.43 & - & - & - & - \\
\hline Winter & 8.67 & 69.33 & 52.41 & 32.58 & 0.97 & 0.44 & 107.54 & 0.87 \\
\hline \multicolumn{9}{|c|}{ Tilia amurensis } \\
\hline Autumn & 5.52 & 73.25 & 54.96 & 45.95 & - & - & - & - \\
\hline Winter & 5.14 & 74.72 & 58.70 & 29.78 & 1.13 & 0.50 & 164.43 & 0.53 \\
\hline \multicolumn{9}{|c|}{ Pinus koraiensis } \\
\hline Winter & 5.33 & 66.01 & 50.37 & 34.47 & 0.18 & 0.21 & 65.10 & 0.42 \\
\hline
\end{tabular}


Table 3. Nutritional quality of red deer diets (on dry matter basis) in the Less Xingan Mountains, northeastern China (1991-1992). See Table 2 for explanations of symbols.

\begin{tabular}{lrrrr}
\hline \multirow{2}{*}{ Component } & \multicolumn{4}{c}{ Season } \\
\cline { 2 - 5 } & Spring & Summer & Autumn & Winter \\
\hline $\mathrm{CP}(\%)$ & 19.61 & 13.51 & 11.55 & 6.35 \\
$\mathrm{NDF}(\%)$ & 55.64 & 63.82 & 67.30 & 69.91 \\
$\mathrm{ADF}(\%)$ & 27.90 & 45.50 & 45.51 & 54.33 \\
$\mathrm{IVDMD}(\%)$ & 61.14 & 55.84 & 48.36 & 32.91 \\
$\mathrm{Ca}(\%)$ & 0.43 & 1.04 & 1.50 & 0.54 \\
$\mathrm{P}(\%)$ & 0.25 & 0.39 & 0.35 & 0.31 \\
$\mathrm{Na}(\mu \mathrm{g} / \mathrm{g})$ & 152.00 & 162.20 & 197.94 & 101.56 \\
$\mathrm{~K}(\%)$ & 2.60 & 2.98 & 1.94 & 0.99 \\
$\mathrm{Ca}: \mathrm{P}$ & $1.7: 1$ & $2.7: 1$ & $4.3: 1$ & $1.7: 1$ \\
$\mathrm{~K}: \mathrm{Na}$ & $171.1: 1$ & $183.7: 1$ & $98.2: 1$ & $97.9: 1$ \\
\hline
\end{tabular}

Hanely (1984) and Leslie et al. (1984), respectively. Another extremely high IVDMD value occurred in red deer winter diets of west central Alberta, Canada (Morgantini and Hudson 1985). Interestingly, Leslie et al. (1984) reported higher dietary $\mathrm{CP}$ values in all seasons except spring than other researchers, whereas

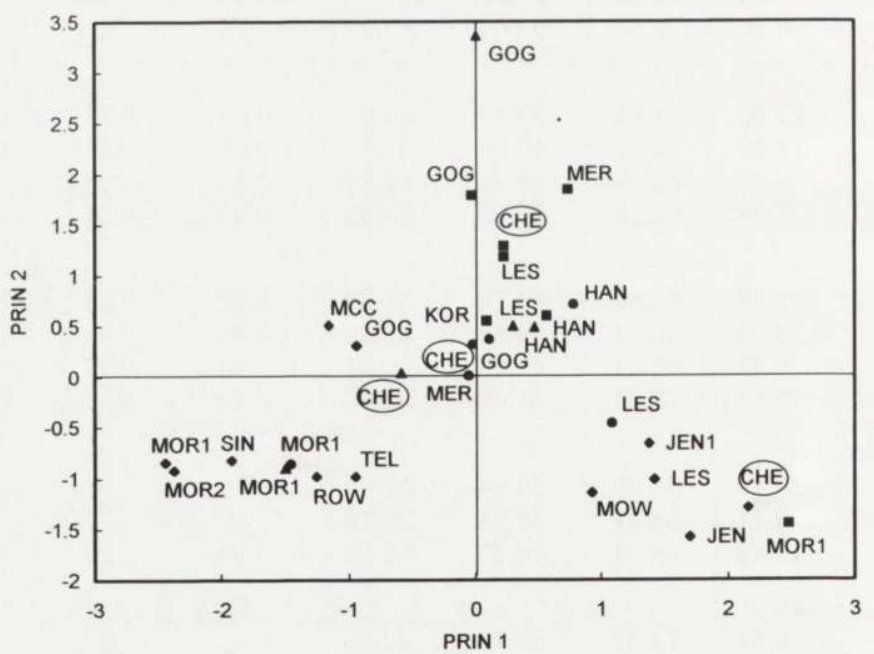

Fig. 1. Principal component analysis of red deer seasonal diet composition in this study region (CHE) and North America (KOR - Korfhage and Nelson 1980, ROW - Rowland et al. 1983, HAN - Hanely 1984, LES - Leslie et al. 1984, MOR2 - Morgantini and Hudson 1985, JEN1 - Jenkins and Wright 1988, MOR1 - Morgantini and Hudson 1989, MOW - Mower and Smith 1989, JEN - Jenkins and Starkey 1993, MCC - McCorquodale 1993, SIN - Singer and Norland 1994, TEL - Telfer 1994, GOG - Gogan and Barrett 1995, MER - Merrill et al. 1995). Triangles - spring, squares - summer, circles - autumn, and diamonds - winter. 


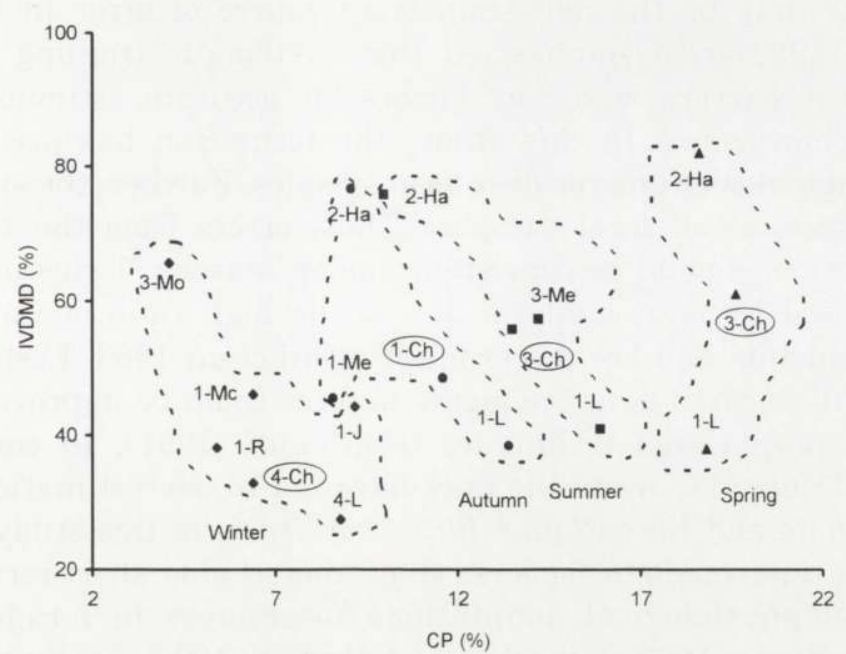

Fig. 2. Crude protein (CP) contents and in vitro dry matter digestibilities (IVDMD) of red deer diets in this study region (Ch) and North America (R - Rowland et al. 1983, Ha - Hanely 1984, L - Leslie et al. 1984, Mo - Morgantini and Hudson 1985, J - Jenkins and Starkey 1993, Mc - McCorquodale 1993, Me - Merrill et al. 1995). For Hanely (data from Tables 2 and 3), Morgantini and Hudson (data from Tables 1 and 2), and McCorquodale (data from Tables 1 and 2), CP and IVDMD values were calculated from data in their papers using the same method as in this study. Arabic numbers represent the numbers of clusters in the cluster analysis. Values with the same number of cluster were grouped in the same cluster.

Hanely (1984), and Morgantini and Hudson (1985) reported lower CP values in summer and winter diets. In our study area, red deer has lower dietary IVDMD values in winter than generally reported (Fig. 2).

\section{Discussion}

The accuracy of fecal analysis to determine herbivore diet composition has been widely investigated by a number of researchers. Serious problems with this method include (1) technician error (Holechek et al. 1982a, b), (2) differential digestibility of plant species (Vavra et al. 1978, Leslie et al. 1983), (3) low discernibility of epidermal fragments due to lack of identifiable characteristics (Todd and Hansen 1973), and (4) sample preparations (Vavra and Holechek 1980, Holechek et al. 1982a). Forbs are often underestimated in fecal analysis because of their high digestibility (Holechek et al. 1982b, McInnis et al. 1983), but this may not be the case in other studies (Todd and Hansen 1973, Alipayo et al. 1992). We assumed that this bias resulted in underestimation of forbs in spring diets in this study because some early spring forbs that were observed to be eaten by red deer in the field were not detected in fecal samples. Holechek et al. (1982a) thought that 
technician error may be the most important source of error in fecal analysis. Alipayo et al. (1992) also emphasized that systematic training and adequate practice by the observers were key factors for accurate estimates of the diet composition of herbivores. In this study, the technician has accumulated over $500 \mathrm{hr}$ analyzing red deer and roe deer fecal samples. Further, the same technician completed analysis of all fecal samples. Thus, errors from the technician and sample preparations should be consistent among seasons. Twigs of browses may be underestimated by fecal analysis due to the high ratio of unidentifiable to identifiable fragments and low discernibility (Gill et al. 1983, Leslie et al. 1983). However, identification of twig fragments in feces could be improved by selecting proper sample preparation techniques (Gao et al. 1991). In contrast, higher discernibility of cuticular fragment may have led to overestimation of the fern, Equisetum hiemale and Korean pine Pinus koraiensis in this study.

Red deer, as intermediate feeders, show remarkable short-term or seasonal anatomical and physiological adaptations to changes in forage quality and availability (Hofmann 1989, Renecker and Hudson 1990, Spalinger et al. 1993, Freudenberger et al. 1994). As a result, a high degree of plasticity exists in diet selection of red deer. Results of the present study are consistent with this argument. In our study area, red deer fed mainly on graminoids in spring, shifted to forbs diets in summer when forbs peaked in biomass, and transferred again to graminoids in autumn when availability of forbs dropped to an extremely low level (H. Chen et al., unpubl.) (Fig. 3). The switch from forbs to grasses also was reported by Merrill (1994). Availability of forbs appeared to be a key factor causing these changes in diets as illustrated in Fig. 3. The other important factor may be the quality of forbs. Recently, Fraser (1996) demonstrated that the greater surface enlargement exists within the rumen of red deer, which indicates a lower

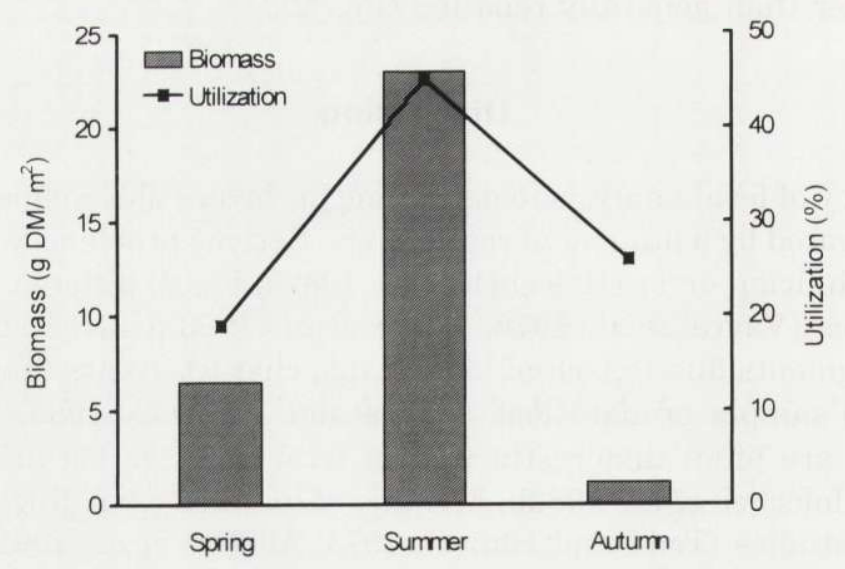

Fig. 3. The biomass and utilization of forbs for red deer in different seasons in the Less Xingan Mountain, Northeastern China (1991-1992). 
adaptation to digestion of fibrous forages. Thus, red deer may avoid fiber as long and as much as possible (Hofmann 1989). Although IVDMD was lower in forbs than in grasses during summer, forbs had higher $\mathrm{CP}$, and lower NDF and ADF than grasses (Table 2). Heavy consumption of forbs in summer is likely due to low fiber contents which may lead to rapid cell-wall breakdown and passage rate (Spalinger et al. 1986) rather than dry matter digestibility. Merrill (1994) reported that no significant difference was found in IVDMD between forbs and grasses during summer. This result tends to support this hypothesis. We and other researchers (Merrill 1994) observed that red deer mainly selected leaves by stripping them off twigs of shrubs and trees in summer and early autumn. In our study area, leaves of most shrubs and trees fall at the end of September, causing a rapid decline in availability of leaves. Thus, the proportion of browses in autumn diets did not increase significantly compared to summer diets. By switching diets from forbs to grasses in autumn, red deer may intake more energy from grasses because a high ratio of reticulum-rumen to body mass allow red deer to digest the cellulose in grasses more completely (Hanely 1982, Hofmann 1989, Merrill 1994).

Habitat, season, climate, altitude, and latitude are main sources of wide regional variation in deer diet composition (Rowland et al. 1983, Tixier and Duncan 1996). In winter, wapiti inhabiting forests mainly fed on browses (Leslie et al. 1984, Jenkins and Starkey 1993, Mower and Smith 1989), whereas in grasslands, prairie, and steppe, graminoids were dominant in the diets because chinooks or mild climate keep those study areas largely snow free (Morgantini and Hudson 1985, 1989, Telfer 1994, Gogan and Barrett 1995) (Fig. 1). In spring, wapiti extremely consumed either graminoids (Morgantini and Hudson 1989) or forbs (Gogan and Barrett 1995) in grasslands and coastal prairie, whereas in forests, graminoids, forbs, and browses were relatively equally used by red deer except a little more graminoids in diets in this study (Fig. 1). Whether in grasslands (Gogan and Barrett 1995, Merrill et al. 1995) or forests (Leslie et al. 1984 and this study), forbs were principal food items in diets during summer. In autumn, habitat cannot explain a large variation in red deer diet composition completely (Fig. 1). Differences in diet composition may have affected diet quality of red deer populations in different habitats. In winter, red deer occupying grasslands had higher dietary IVDMD but lower dietary CP than red deer in forests (Fig. 2). Diets of red deer in grasslands were dominated by grasses which contained much higher IVDMD but lower CP than browses that were principal food items in diets of wapiti in forests (Hobbs et al. 1981, Rowland et al. 1983, McCorquodale 1993). Thus, it may be assumed that red deer will be more limited by energy in forests than in grasslands during severe winter.

$\mathrm{Li}$ and Yan (1989) reported seasonal composition of red deer diets in the Less Xingan Mountains, northeastern China. Their results showed that herbaceous plants dominated spring diets $(87 \%)$, but more than $85 \%$ of diets were composed of browses in other seasons. These results were very different from ours. We suspected that forbs were extremely underestimated or even neglected in their 
study because their results were from analysis of only four rumen samples, one in each season. In most studies, including our previous work (Chen and Xiao 1989, Chen et al. 1993), contribution of ferns to diets was small and ignored. However, Leslie et al. (1984) reported high percentages of fern in spring and winter diets of elk (25-37\%). Much use of the horsetail, Equisetum hiemale, in this study, probably has two reasons. One is that ferns are easily overestimated because their cuticular fragments usually have higher discernibility (Todd and Hansen 1973). This is particularly true for E. hiemale because of its large and easily discernible fragments. The other, maybe more important, is the shortage of forages in winter. In our study area, biomass of forages dropped to the lowest level in winter $(22.9 \mathrm{~g}$ $\mathrm{DM} / \mathrm{m}^{2}$ in clearcuts) compared with other seasons $\left(42.3-168.5 \mathrm{~g} \mathrm{DM} / \mathrm{m}^{2}\right)(\mathrm{H}$. Chen et al., unpubl.). Further, the area of clearcuts as suitable winter feeding habitats (Zhang and Xiao 1990) was smaller because forests have been logged selectively in this region. This was further confirmed by our observation during winter investigation. In January and February, red deer often cratered in snow to feed on green herbaceous plants and ferns. Moreover, bark of Ulmus spp. was commonly stripped in February. We measured 31 stripped Ulmus trees and found that average diameter at breast height was $4.4 \mathrm{~cm}(3-8.5 \mathrm{~cm})$, and the mean of the highest stripped points to the ground was $1.8 \mathrm{~m}(0.5-3 \mathrm{~m})$. Stripping of trees was also reported in eastern Europe (Jamrozy 1980, Matrai and Kabai 1989). Jamrozy (1980) found that red deer stripped bark from 27 tree species and estimated that bark amounted to about $25 \%$ of winter diets.

Ammann et al. (1973) suggested that 50\% digestible dry matter in white-tailed deer diets was required to maintain positive energy balance. In most seasons, dietary IVDMD of red deer in this study area was greater than or close to this threshold except in winter (Table 3). Thus, we can infer that red deer would maintain a positive energy balance in snow-free seasons, but in winter energy probably become an important limiting factor. There is limited information on the protein nutrition at various physiological stages. Until recently, protein requirements for growth and production of red deer have to be extrapolated from domestic ruminants using the factorial approach. For red deer hinds, dietary $\mathrm{CP}$ contents for growth and production increase from $10 \%$ in autumn/winter (dry) to $17 \%$ in summer (lactation), and for stags, from $10 \%$ in autumn/winter to $12 \%$ in spring/summer (Adam 1991). Therefore, dietary CP contents of $12-20 \%$ during snow-free seasons in our study area are generally considered adequate for meeting protein requirements during period of growth and production. $\mathrm{CP}$ content in winter diets $(6 \%)$ exceeded generally accepted $5-5.7 \%$ for meeting metabolic nitrogen requirements (Maloiy et al. 1970, Mould and Robbins 1981, Nelson and Leege 1982) but was lower than 10\% needed for growth (Adam 1991). Digestion of protein can be influenced by soluble phenolics, like tannins, which bind protein to form irreversible complexes, thereby reducing protein availability and digestibility of cell solubles (Robbins et al. 1987a, b). Thus, concentrations of secondary plant compounds in forages may alter the relative value of diet quality. However, 
salivary protein of red deer may have a high capacity to bind tannins, hence reducing effects of tannins (Hagerman and Robbins 1993).

Deficiencies and imbalances of minerals affect animal condition, fertility, productivity, and mortality (Robbins 1983). Recently, the importance of mineral nutrition has received considerable attention in diet selection, spatial distribution and seasonal movement of wild herbivores at population and ecosystem level (Bazely 1989, McNaughton 1988, 1990). However, information on mineral nutrition in cervids has been very limited. In our study, dietary $\mathrm{K}$ was higher in spring and summer than in autumn and winter (Table 3). This pattern was reported by Weeks and Kirkpatrick (1976) for white-tailed deer. Similarly, Leslie et al. (1984) observed the same pattern for $\mathrm{P}$ content in elk diets. In contrast, dietary $\mathrm{Ca}, \mathrm{P}$ and $\mathrm{Na}$ in this study were higher in summer and autumn, and lower in spring and winter (Table 3). Dietary Ca to $\mathrm{P}$ ratios ranging from 1:1 to 2:1 are considered to be ideal for proper absorption and metabolism (Robbins 1983). Dietary ratios of $\mathrm{Ca}$ to $\mathrm{P}$ fall in these optimal ranges in spring and winter $(1.7: 1)$, but deviate from the ideal ratios in summer (2.7:1), and especially in autumn (4.3:1) in this study. However, excesses of Ca may have a far lesser effect on $\mathrm{P}$ absorption than do excesses of $\mathrm{P}$ on Ca absorption (Robbins 1983). Weeks and Kirkpatrick (1976) suggested that high intake of $\mathrm{K}$ led to excessive $\mathrm{Na}$ loss and a temporary negative $\mathrm{Na}$ balance. However, Christian (1989) found that $\mathrm{Na}$ loss and balance were not significantly affected by high dietary K content in small mammals. In this study, K : Na ratios (Table 3) are much lower than reported by Weeks and Kirkpatrick (1976) for white-tailed deer (156-485). Thus, the problem of high dietary K content resulting in $\mathrm{Na}$ loss and imbalance might not be serious, even if it occurred in red deer.

We know little about requirements for $\mathrm{Ca}, \mathrm{P}, \mathrm{Na}$ and $\mathrm{K}$ in wild large herbivores. Some information has to be obtained from domestic ruminants. Until recently, the only available data for Ca requirements are $0.37 \%$ for red deer (Muir et al. 1987, the average of two individuals, calculated from rates of Ca deposition in the antlers and net fecal endogenous losses) and $0.4-0.64 \%$ for white-tailed deer reported by McEwen et al. (1957) and Ullrey et al. (1973). Recently, Grasman and Hellgren (1993) reported the lower $\mathrm{P}$ requirements $(0.11-0.16 \%)$ for white-tailed deer than the generally accepted value of $0.20-0.25 \%$ for mule deer reported by Short (1981). Pletscher (1987) indicated that minimum Na requirements were $0.017-0.038 \%$ for white-tailed deer, far lower than the estimate for domestic ruminants, $0.1-0.2 \%$ (Maynard et al. 1979). Robbins (1983) also suggested that $\mathrm{Na}$ requirements of birds and mammals would reach $0.05-0.15 \%$ during growth and reproduction. Maynard et al. (1979) reported that critical level of $\mathrm{K}$ was $0.20-0.30 \%$ for domestic ruminants. Therefore, according to above data, we can infer that $\mathrm{Ca}, \mathrm{P}, \mathrm{K}$ in seasonal red deer diets are adequate in most cases, but Na might appear deficient throughout the year.

It is concluded that diet of red deer in our region is characteristic of mixed feeders (Hofmann 1989). The diet of our red deer undergoes to similar seasonal 
changes in quality as that of North American wapiti. Although red deer have enough protein in most seasons, energy may be a key limiting factor in severe winters.

Acknowledgments: We thank numerous personnel from the Tonghe Hunting Farm for the field assistance. Special thanks to Du Yongxin and $\mathrm{Li}$ Jie, managers of farm, who graciously contributed their time and effort in completing this study. We are very grateful to Nie Shaoquan. Huang Puhua, Dian Xingjun and Yang Guoting for identifying and classifying plant specimens, and Bi Shoufa, Yang Shouzhuang, Wang Yuyan and Yang Zhunhua for assistance with laboratory analysis. We also thank Professors R. Hudson and Z. Pucek, Mr J. Gedir, and other three anonymous reviewers for their helpful comments on the early draft of this manuscript. This study was supported by the National Nature Science Foundation of China (No. 39070160).

\section{References}

Adam C. L. 1991. Nutrition and the implications of modifying the seasonality of farmed red deer. [In: Recent advances in animal nutrition. W. Haresign and D. J. A. Cole, eds]. Butterworth-Heinemann Ltd., Oxford: 211-223.

Alipayo D., Valdez R., Holechek J. L. and Cardenas M. 1992. Evaluation of microhistological analysis for determining ruminant diet botanical composition. Journal of Range Management 45: 148-152.

Ammann A. P., Cowan R. L., Mothershead C. L. and Baumgardt B. R. 1973. Dry matter and energy intake in relation to digestibility in white-tailed deer. Journal of Wildlife Management 37: $195-201$.

Anthony R. G. and Smith N. S. 1974. Comparison of rumen and fecal analysis to describe deer diets. Journal of Wildlife Management 38: 535-540.

Baker D. L. and Hobbs N. T. 1982. Composition and quality of elk summer diets in Colorado. Journal of Wildlife Management 46: 694-703.

Baker D. L. and Hobbs N. T. 1987. Strategies of digestion: digestive efficiency and retention time of forage diets in montane ungulates. Canadian Journal of Zoology 65: 1978-1984.

Bazely D. R. 1989. Carnivorous herbivores: mineral nutrition and the balanced diet. Trends in Ecology and Evolution 4: 155-156.

Bell R. H. V. 1970. The use of the herb layer by grazing ungulates in the Serengeti. [In: Animal populations in relation to their food resources, Tenth symposium of the British Ecological Society. A. Watson, eds]. Blackwell Scientific Publications, Oxford: 111-123.

Bell R. H. V. 1971. A grazing ecosystem in the Serengeti. Scientific American. 224: 86-93.

Byers C. R., Steinhorst R. K. and Krauseman P. R. 1984. A clarification of a technique for analysis of utilization-availability data. Journal of Wildlife Management 48: 1050-1053.

Chen H. P., Ma J. Z., Li F., Wang Y. H., Wang H. and Li F. 1993. Regional variation in winter diets of red deer in Heilongjiang, northeastern China. [In: Deer of China: biology and management. N. Ohtaishi and H. L. Sheng, eds]. Elsevier Science Publishers B. V., Amsterdam: 181-186.

Chen H. P. and Xiao Q. Z. 1989. Winter food-habits of red deer in Dailing. Acta Theriologica Sinica 9: 8-15. [In Chinese with English summary]

Christian D. P. 1989. Effects of dietary sodium and potassium on mineral balance in captive meadow voles (Microtus pennsylvanicus). Canadian Journal of Zoology 68: 168-177.

Clutton-Brock T. H. and Albon S. D. 1989. Red deer in the Highlands. BSP Professional Books, Oxford: $1-260$

Clutton-Brock T. H., Guinness F. E. and Albon S. D. 1982. Red deer: behavior and ecology of two sexes. University of Chicago Press, Chicago: 1-378.

Cullison A. E. 1982. Feeds and feeding (3rd ed). Reston Publishing Company, Inc., Reston, Virginia: 1-628. 
Demment M. W. and Van Soest P. J. 1985. A nutritional explanation for body-size patterns of ruminant and non ruminant herbivores. American Naturalist 125: 641-672.

Fracker s. B. and Brischle J. A. 1944. Measuring the local distribution of Rebes. Ecology 25: 283-303.

Fraser K. W. 1996. Comparative rumen morphology of sympatric sika deer (Cervus nippon) and red deer (C. elaphus scoticus) in the Ahimanawa and kaweka Ranges, central North Island, New Zealand. Oecologia 105: 160-166.

Freudenberger D. O., Toyakawa K., Barry T. N. and Ball A. J. 1994. Seasonality in digestion and rumen metabolism in red deer (Cervus elaphus) fed on a forage diet. British Journal of Nutrition 71: $489-499$.

Gao Z. X., Chen H. P. and Wang X. P. 1991. Evaluation of fecal analysis for determining food habits of herbivores. Acta Theriologica Sinica 11: 186-193. [In Chinese with English summary]

Gębczyńska Z. 1980. Food of the roe deer and red deer in the Białowieża Primeval Forest. Acta Theriologica 25: 487-500.

Geist V. 1987. On speciation in Ice Age mammals, with special reference to cervids and caprids. Canadian Journal of Zoology 65: 1067-1084.

Gill R. B., Carpenter L. H., Bartmann R. M., Baker D. L. and Schonveld G. G. 1983. Fecal analysis to estimate mule deer diets. Journal of Wildlife Management 47: 902-913.

Goering H. K. and Van Soest P. J. 1970. Forage fibre analysis: apparatus, procedures, and some applications. The Unite States Department of Agriculture, Agricultural Handbook: 1-379.

Gogan P. J. P. and Barrett R. H. 1995. Elk and diets in a coastal prairie-shrub Mosaic, California Journal of Rang Management 48: 327-335

Goldsmith F. B. and Harrison C. M. 1976. Description and analysis of vegetation. [In: Methods in plant ecology. S. B. Chapman, eds]. Blackwell Scientific Publications, Oxford: 85-155.

Gordon I. J. and Illius A. W. 1996. The nutritional ecology of African ruminants: a reinterpretation. Journal of Animal Ecology 65: 18-28.

Grasman B. T. and Hellgren E. C. 1993. Phosphorus nutrition in white-tailed deer: nutrient balance, physiological response, and antler growth. Ecology 74: 2279-2296.

Hagerman A. E. and Robbins C. T. 1993. Specificity of tannin-binding salivary proteins relative to diet selection by animals. Canadian Journal of Zoology 71: 628-633.

Hanely T. A. 1982. The nutritional basis for food selection by ungulates. Journal of Range Management 35: 146-151.

Hanely T. A. 1984. Habitat patches and their selection by wapiti and black-tailed deer in a coastal montane coniferous forest. Journal of Applied Ecology 21: 423-436.

Hobbs N. T., Baker D. L., Ellis J. E. and Swift D. M. 1981. Composition and quality of elk winter diets in Colorado. Journal of Wildlife Management 45: 156-171.

Hofmann R. R. 1989. Evolutionary steps of ecophysiological adaptation and diversification of ruminants: a comparative view of their digestive system. Oecologia 78: 443-457.

Hofmann R. R. and Stewart D. R. M. 1972. Grazer or browser: a classification based on the stomach structure and feeding habits of East African ruminants. Mammalia 36: 226-240.

Holechek J. L., Gross B., Dabo S. M. and Stephenson T. 1982a. Effects of sample preparation, growth stage and observer on microhistological analysis of herbivore diets. Journal of Wildlife Management 46: 502-505.

Holechek J. L., Vavra M. and Pieper R. D. 1982b. Botanical composition determination of range herbivore diets: a review. Journal of Range Management 35: 309-315.

Illius A. W. and Gordon I. J. 1987. The allometry of food intake in grazing ruminants. Journal of Animal Ecology 56: 989-1000.

Illius A. W. and Gordon I. J. 1990. Variation in foraging behavior in red deer and the consequences for population demography. Journal of Animal Ecology 59: 89-101.

Jamrozy G. 1980. Winter food resources and food preferences of red deer in Carpathian forests. Acta Theriologica 25: 221-238. 
Jarman P. J. 1974. The social organization of antelope in relation to their ecology. Behaviour 48: 215-267.

Jenkins K. J. and Starkey E. E. 1993. Winter forage and diets of elk in old-growth and regenerating coniferous forests in western Washington. American Midland Naturalist 130: 299-313.

Jenkins K. J. and Wright R. G. 1988. Resource partitioning and competition among cervids in the northern Rocky Mountains. Journal of Applied Ecology 25: 11-24.

Jenks J. A., Leslie D. M., Jr, Lochmiller R. L., Melchiors M. A. and Warde W. D. 1989 Effect of compositing samples on analysis of fecal nitrogen. Journal of Wildlife Management 53: 213-215.

Korfhage R. C. and Nelson J. R. 1980. Summer diets of Rocky Mountain elk in northeastern Oregon. Journal of Wildlife Management 44: 746-750.

Leslie D. M., Jr, Starkey E. E. and Vavra M. 1984. Elk and deer diets in old-growth forests in western Washington. Journal of Wildlife Management 48: 762-775.

Leslie D. M., Jr, Vavra M., Starkey E. E. and Slater R. C. 1983. Correcting for differential digestibility in microhistological analysis involving common coastal forages of the Pacific Northwest. Journal of Range Management 36: 730-732.

Li Y. Z., Xiao Q. Z. and Chen H. P. 1992. Interspecific relationships among moose, red deer and roe deer in winter. Acta Theriologica Sinica 12: 110-116. [In Chinese with English summary]

Li J. C. and Yan T. F. 1989. Food habits of wild red deer and its damage to young forest. Chinese Journal of Zoology 24: 34-36. [In Chinese]

Maloiy G. M. D., Kay R. N. B. and Goodall E. D. 1970. Digestion and nitrogen metabolism in sheep and red deer given large or small amounts of water and protein. British Journal Nutrition 24: 843-855.

Matrai K. and Kabai P. 1989. Winter plant selection by red and roe deer in a forest habitat in Hungary. Acta Theriologica 34: 227-234.

Maynard L. A., Loosli J. K., Hintz H. F. and Wagner R. G. 1979. Animal nutrition. 7th. ed. McGraw-Hill Book Co., New York: 1-602.

McCorquodale S. M. 1993. Winter foraging behavior of elk in the shrub-steppe of Washington. Journal of Wildlife Management 57: 881-890.

McEwen L. C., French C. E., Magruder N. D., Swift R. W. and Ingram R. H. 1957. Nutrient requirements of the white-tailed deer. Transactions of North America Wildlife Conference 22 119-132.

McInnis M. L., Vavra M. and Krueger W. C. 1983. A comparison of four methods used to determine the diets of large herbivores. Journal of Range Management 36: 302-306.

McNaughton S. J. 1988. Mineral nutrition and spatial concentrations of African ungulates. Nature 334: 343-345.

McNaughton S. J. 1990. Mineral nutrition and seasonal movements of African migratory ungulates. Nature 345: 613-615.

Merrill E. H. 1994. Summer foraging ecology of wapiti (Cervus elaphus roosevelti) in the Mount St. Helens blast zone. Canadian Journal of Zoology 72: 303-311.

Merrill E. H., Callahan-Olson A., Raedeke K. J., Taber R. D. and Anderson R. J. 1995. Elk (Cervus elaphus roosevelti) dietary composition and quality in the Mount St. Helens blast zone. Northwest Science 69: 9-18.

Morgantini L. E. and Hudson R. J. 1985. Changes in diets of wapiti during a hunting season. Journal of Range Management 38: 77-79.

Morgantini L. E. and Hudson R. J. 1989. Nutritional significance of wapiti (Cervus elaphus migrations to alpine ranges in western Alberta, Canada. Arctic and Alpine Research 21: 288-295.

Mould E. D. and Robbins C. T. 1981. Nitrogen metabolism in elk. Journal of Wildlife Management 45: $323-334$

Mower K. J. and Smith H. D. 1989. Diet similarity between elk and deer in Utah. Great Basin Naturalist 49: 552-555. 
Muir P. D., Sykes A. R. and Barrell G. K. 1987. Calcium metabolism in red deer (Cervus elaphus) offered herbage during antlerogenesis: kinetic and stable balance studies. Journal of Agricultural Science (Cambridge) 109: 357-364.

Nelson J. R. and Leege T. A. 1982. Nutritional requirements and food habits. [In: Elk of North America: ecology and management. J. W. Thomas and D. E. Toweill, eds]. Stackpole Books, Harrisburg, Pennsylvania: 323-368.

Ohtaishi N. and Gao Y. T. 1990. A review of the distribution of all species of deer (Tragulidae, Moschidae and Cervidae) in China. Mammal Review 20: 125-144.

Pearson H. A. 1970. Digestibility trials: in vitro techniques. [In: Range and wildlife habitat evaluation: a research symposium. United States Department of Agriculture, Forestry Service, Miscellaneous Publication No. 1147]. United States Forestry Service, Washington: 85-92.

Pletscher D. H. 1987. Nutrient budgets for white-tailed deer in New England with special reference to sodium. Journal of Mammalogy 68: 330-336.

Renecker L. A. and Hudson R. J. 1990. Digestive kinetics of moose (Alces), wapiti (Cervus elaphus) and cattle. Animal Production 50: 51-61.

Robbins C. T. 1983. Wildlife Feeding and Nutrition. Academic Press, New York: 1-343.

Robbins C. T., Hanely T. A., Hagerman A. E., Hjeljord O., Baker D. L., Schwartz C. C. and Mautz W. W. 1987a. Role of tannins in defending plants against ruminants: reduction in protein availability. Ecology 68: 98-107.

Robbins C. T., Mole S., Hanely T. A. and Hagerman A. E. 1987b. Role of tannins in defending plants against ruminants: reduction in dry matter digestion. Ecology 68: 1606-1615.

Rowland M. M., Alldredge A. W., Ellis J. E., Weber B. J. and White G. C. 1983. Comparative winter diets of elk in New Mexico. Journal of Wildlife Management 47: 924-932.

SAS 6.0. 1989. SAS users guide: statistics. SAS Institute Inc., Cary, N. C.: 1-890.

Sheng H. L. 1992. Red deer Cervus elaphus. [In: The deer in China. H. L. Sheng, ed]. East China Normal University Press, Shanghai: 1-305

Sheng H. L. and Ohtaishi N. 1993. The status of deer in China. [In: Deer of China: biology and management. N. Ohtaishi and H. L. Sheng, eds]. Elsevier Science Publishers B.V., Amsterdam: $1-11$.

Short H. L. 1981. Nutrition and metabolism. [In: Mule and black tailed deer of North America. O. C. Wallmo, ed]. University of Nebraska Press, Lincoln: 99-128.

Singer F. J. and Norland J. E. 1994. Niche relationships within a guild of ungulate species in Yellowstone National Park, Wyoming, following release from artificial controls. Canadian Journal of Zoology 72: 1382-1394.

Spalinger D. E., Robbins C. T. and Hanely T. A. 1986. The assessment of handling time in ruminants: the effect of plant chemical and physical structure on the rate of breakdown of plant particles in the rumen of mule deer and elk. Canadian Journal of Zoology 64: 312-321.

Spalinger D. E., Robbins C. T. and Hanely T. A. 1993. Adaptive rumen function in elk (Cervus elaphus nelsoni) and mule deer (Odocoileus hemionus hemionus). Canadian Journal of Zoology 71: 601-610.

Sparks D. R. and Malechek J. C. 1968. Estimating percentage dry weight in diets using a microscopic technique. Journal Range Management 21: 264-265.

Steel R. G. D. and Torrie J. H. 1980. Principles and procedures of statistics. McGraw-Hill Book Co., New York: $1-481$.

Storr G. M. 1961. Microscopic analysis of feces, a technique for ascertaining the diet of herbivorous mammals. Australian Journal of Biological Science 14: 157-164.

Telfer E. S. 1994. Cattle and cervid interactions on a foothills watershed in southwestern Alberta. Canadian Field-Naturalist 108: 186-194.

Tixier H. and Duncan P. 1996. Are European roe deer browers? a review of variations in the composition of their diets. Review of Ecology 51: 3-17. 
Todd J. W. and Hansen R. M. 1973. Plant fragments in the feces of bighorns as indicators of food habits. Journal of Wildlife Management 37: 363-366.

Ullrey D. E., Youatt W. G., Johnson H. E., Fay L. D., Schoepke B. L., Magee W. T. and Keahey K. K. 1973. Calcium requirements of weaned white-tailed deer fawns. Journal of Wildlife Management 37: $187-194$

Urness P. L., Neff D. L. and Vahie J. P. 1975. Nutrient content of mule deer diets from Ponderosa pine range. Journal of Wildlife Management 39: 670-673.

Vavra . I. and Holechek J. C. 1980. Factors influencing microhistological analysis of herbivore diets. Journal Range Management 33: 371-374.

Varra M., Rice R. W. and Hansen R. M. 1978. A comparison of esophageal fistula and fecal materials to determine deer diets. Journal of Range Management 31: 11-13.

Weeks H. P. and Kirkpatrick C. M. 1976. Adaptations of white-tailed deer to naturally occurring sodium deficiencies. Journal of Wildlife Management 40: 610-625.

Zhang M. H. and Xiao Q. Z. 1990. A study on feeding and bedding habitat selection by red deer in winter. Acta theriologica Sinica 10: 175-183. [In Chinese with English summary]

Received 3 December 1996, accepted 15 September 1997. 